schools or broad socioeconomic factors as well as, perhaps most importantly, the pivotal role of classroom instructors in embracing or limiting instructional and curriculum changes in history education. While his analysis of secondary history teaching is admittedly limited, Cuban's book is highly relevant to all history teachers. Issues such as teacher education, Advanced Placement courses, federal Teaching American History grants, and the preparation of future undergraduates as well as citizens in a society in which history education is increasingly politicized underscore the inevitable links between the teaching of history in secondary schools and in higher education.

\title{
Teaching History Then: The Origins of the Journal and The History Teaching Movement of the 1970s
}

\author{
Richard L. Hughes
}

One way to explore changes and continuities in history education in the last forty years, especially in higher education, is to examine the evolution of Teaching History: A Journal of Methods. Teaching History grew out of conversations at the Missouri Valley History conference in 1974 and 1975. With support from Emporia Kansas State College as well as the interest of college and university faculty, secondary teachers, and public historians, Stephen Kneeshaw (editor) and Ron Butchart (book review editor) published the inaugural issue in the Spring of 1976. The journal aimed to address the following topics: "Teaching technology and techniques; trends in textbooks; trends in historical scholarship; philosophical essays on the teaching of history; curricula; and reports on innovative experiments." The goal was that the journal would "provide history teachers with another outlet for the presentation and discussion of innovative techniques and teaching methods."

It is tempting to think of the mid-seventies as a promising time for the discipline of history in American society. The U.S. Bicentennial brought countless efforts to reflect on our nation's past, and Alex Haley's Roots: The Saga of an American Family (1976), which spent almost a year on The New York Times Bestseller List in 1976-77,

'Stephen John Kneeshaw, "History of Teaching History," Teaching History: A Journal of Methods 1 (1976): 1.

${ }^{2}$ Ibid. 
fueled a renewed interest in both African American history and genealogy. ${ }^{3}$ However, the dominant theme of most discussions of history at the time was one of crisis. Gordon Wright, president of the American Historical Association (AHA), spoke of "Clio in Hard Times" in 1975. ${ }^{4}$ That same year, the Organization of American Historians' $(\mathrm{OAH})$ Ad Hoc Committee on the Status of History in the Schools published a report that stressed the challenges of decreasing enrollment in higher education and curriculum changes, in both colleges and high schools, that reflected a move away from history. ${ }^{5}$ In his April 1976 OAH Presidential Address, entitled "American Historians: A Bicentennial Appraisal," Frank Freidel referred to the "crisis" in history twice- just in his introduction - and then referred to, among other problems, the "malaise in the teaching of history in the schools."

Articles in popular publications such as Newsweek and TV Guide lamented the erosion of historical literacy. ${ }^{7}$ In May 1976, just weeks after the arrival of the inaugural issue of Teaching History, The New York Times released the troubling results of a nationwide survey that assessed college freshmen's knowledge of American history. While the results of the survey were somewhat mixed and relatively close to a similar test in 1943, the tone of the commentary on the exam was clear. The Times emphasized "startling gaps" in the knowledge of college students and "decreasing emphasis on American history" in the nation's schools. ${ }^{8}$ William Leuchtenburg, a historian from Columbia University and one of the architects of the exam, reminded readers that "The main conclusion one must draw is unmistakable; that this group of students knows remarkably little American history." $"$

Not surprisingly, the dominant theme of much of the first four issues of Teaching History was, as Kneeshaw described it in the journal's first essay, "something is rotten in the historical profession." In "Crisis in the Classroom: Clio Down but Not Out,"

${ }^{3}$ Alex Haley, Roots: Saga of an American Family (New York: Doubleday, 1976).

${ }^{4}$ Gordon Wright, "Clio in Hard Times," AHA Newsletter 13 (January 1975): 2.

${ }^{5}$ Richard J. Kirkendall, "The Status of History in the Schools," Journal of American History 62 (September 1975): 557-570.

${ }^{6}$ Frank Freidel, “American Historians: A Bicentennial Approach,” Journal of American History 63 (June 1976): 5 .

7“"History as Bunk," Newsweek, November 10, 1975, 84-86; John P. Roche, "Does the TV Generation Lack a Sense of History?" TV Guide, November 15, 1975, A-3.

${ }^{8}$ Edward B. Fiske, "Times Test of College Freshman Shows Knowledge of American History Limited," The New York Times, May 2, 1976, 1.

${ }^{9}$ Ibid. 
Kneeshaw summarized the challenges facing the profession and some of the initial efforts by organizations such as the AHA and $\mathrm{OAH}$ to improve classroom teaching in the seventies. ${ }^{10}$ Subsequent issues continued the emphasis on "the apparent crises of history in the classroom" that could no longer "be ignored." James C. Maroney and William J. McNeill described the "plight of the discipline" in a climate of expanding higher education that increasingly questioned the relationship between historical scholarship and teaching. ${ }^{12}$ Essays on promising new approaches to teaching often began or ended with references to the spate of "obituary notices" for the discipline and the need for solutions as "a tool for Clio's survival."13

However, most of the essays in the early issues of Teaching History also embraced a point stressed in Freidel's Presidential Address in 1976, that "it is one of our most salutary American traditions in time of crisis to seek new opportunities." ${ }^{14}$ Contributors argued that the current crisis demanded creative and ambitious innovation in the classroom. Essays in the journal's first four issues addressed such topics as enriching the teaching of history through television and film, developing oral history projects for colleges and secondary schools, and the benefits of quantitative history in the classroom. Essays also included discussions of using folk music, counter-factual history, and opportunities for assignments in which students crafted historical narratives from the perspective of the future. Historians offered detailed accounts of existing efforts to use learning contracts or what was referred to at the time as "personalized systems of instruction" (PSIs). Other articles addressed the role of gender in the discipline - "Is Clio Still Sexist?"- and strategies for teaching women's history. ${ }^{15}$ A few contributors were especially sensitive to criticisms of history teaching and offered detailed curriculum experiments designed to move away from traditional lectures toward survey courses centered on student-centered laboratory exercises.

\footnotetext{
${ }^{10}$ Stephen John Kneeshaw, "Crisis in the Classroom: Clio Down but Not Out," Teaching History: A Journal of Methods 1 (Spring 1976): 2-5.
}

${ }^{11}$ Myron Marty, "Trends and Trendiness in Teaching Undergraduate History," Teaching History: A Journal of Methods 1 (Fall 1976): 42.

${ }^{12}$ James C. Maroney and William J. McNeill, "Teaching College History: A Critique and Historiographical Analysis,” Teaching History: A Journal of Methods 2 (Spring 1977): 1.

\footnotetext{
${ }^{13}$ Jean D. Moss, “Aim, Matter, and Method,” Teaching History: A Journal of Methods 2 (Spring 1977): $8,20$.
}

${ }^{14}$ Freidel, 5 .

${ }^{15}$ Glenda Riley, "Is Clio Still Sexist? Women's History in Recent American History Texts," Teaching History: A Journal of Methods 1 (Spring 1976): 15-24. 
The book reviews in the early issues of the journal were also revealing about the mission and identity of the journal. Butchart explained in the first issue that "reviews will be concerned with the pedagogical more than the scholarly merits of the materials" in the hope that such reviews would "aid" teachers of history and "fill a need not met by other professional journals." ${ }^{16}$ As a result, the first book reviews in Teaching History included a textbook for an undergraduate methods course, anthologies of valuable primary sources, and a reader for classes in Western Civilization. Some of the issues commented on teaching films and other curriculum materials. Elsewhere the journal reviewed the sort of monographs reviewed in more traditional academic journals. However, in these cases the reviews typically included at least some attention to the value of the book in terms of the teaching and learning of history. In contrast to later volumes which included mostly reviews of traditional monographs, the early issues of the journal included numerous reviews of college textbooks. For example, in a piece entitled, "Textbooks and the Crisis of Classroom Teaching," the Fall 1977 issue included an often scathing review essay of four popular college textbooks in U.S. history. Once again, the context of professional crisis informed the review essay as the author, James L. McElroy, stressed the inherent limitations of textbooks as a solution. The author criticized the "false hopes" of publishers and warned that "grand ambitions and illusory promises in our textbooks will continue to raise expectations falsely, while both history enrollments and students' performance on sample exams remain distressingly low." ${ }^{17}$

While the early issues of Teaching History reflected what one author identified as a palpable "history teaching movement" committed to experimentation and reform, many of these thoughtful efforts relied primarily on anecdotal evidence of meaningful classroom experiences. ${ }^{18}$ Readers encountered personal reflections of innovative classroom strategies, bold attempts to promote curricular reform to meet the challenges of a new era, and sometimes insightful accounts of failures. Some essays included detailed class materials such as course outlines, actual learning contracts, and assessments. Such efforts provided readers with new experiences and insights from fellow instructors, some of whom taught at small liberal arts colleges, community colleges, and junior colleges that were largely overlooked by more traditional journals such as the American Historical Review and the Journal of American History. As Kneeshaw explained in the inaugural issues, "we must rely on ourselves" to improve

\footnotetext{
${ }^{16}$ Ronald E. Butchart, “About the Reviews in Teaching History," Teaching History: A Journal of Methods 1 (Spring 1976): 34.

${ }^{17}$ James L. McElroy, "Textbooks and the Crisis of Classroom Teaching," Teaching History: A Journal of Methods 2 (Fall 1977): 67-73.
}

${ }^{18}$ Marty, 43. 
the teaching of history, and the content of the journal in 1976 and 1977 suggests an impressive faith in historians from different types of institutions as teachers capable of creating meaningful change. ${ }^{19}$

However, some of the contributors also addressed the perils of reckless experimentation or "trendiness" in the classroom. In "Teaching College History: A Critique and Historiographical Analysis," Maroney and McNeill called for history teachers to "submit their findings to vigorous analysis" and then "derive interpretations from which corrective action should emanate." ${ }^{20}$ Similarly, a number of essays approached the teaching of history with systematic efforts to compile and analyze data of student learning. Early examples in the journal included articles such as "Clio and Keller: PSI and the History Classroom," "An Abortive Experiment in World History," and "An Argument for Freedom of Choice." 21 This small body of work, early in the journal's history, foreshadowed the growing concern about assessment in secondary and higher education and the emergence of the Scholarship of Teaching and Learning (SoTL) in history.

\footnotetext{
${ }^{19}$ Kneeshaw, "Crisis in the Classroom: Clio Down but Not Out," 3.

${ }^{20}$ Maroney and McNeill, 5 .

${ }^{21}$ David McComb, "Clio and Keller: PSI and the History Classroom," Teaching History: A Journal of Methods 1 (Spring 1977): 17-21; William L. Burton, "An Abortive Experiment in World History," Teaching History: A Journal of Methods 2 (Fall 1977): 50-53; David E. Kyvig, "An Argument for Freedom of Choice,” Teaching History: A Journal of Methods 1 (Spring 1976): 28-33.
} 